\title{
MY SOCIOLOGICAL STEWARDSHIP: PART I
}

By Carroll D. Clark

Copyright, 1969, by the author

Being discursive and subjective extracts on miscellaneous episodes from such parts of my life history as bear significantly on my half century of association with the University of Kansas. The extracts herewith presented may be taken as a sample of incidents that attended my discovery of sociology, and my role as a member of the K.U. Sociology Department. On no account should they be taken as a piece of serious historical research. Most of the articles touched on here are drawn from memory, either as I recall them from direct experience or from accounts given by friends, colleagues or others whose credibility I accepted at the time. I need scarcely warn the readers of a sociological journal of the fallibility, selectivity, and Bartlettian caprices of human remembering and forgetting.

\section{Prologue}

On numerous occasions I have been importuned to do a history of the K.U. Sociology Department. It was argued by fellow staff members that no one living had experienced so many years of association with the Department. Several colleagues in other departments of the university held that none now alive had dabbled in so many interdepartmental projects, served on such a variety of college and university committees, or been drawn into more quixotic academic innovations and extra curricular adventures. Moreover, it was suggested by friends within and without the university community, when the subject was opened (as it was with increasing frequency in the later years of my active stewardship on the faculty) that an enterprise of such sort as to involve historical research in a sociological setting would be "simply wonderful" for an emeritus professor of my background, since it could be extended indefinitely by means of intensive investigation into a multitude of small incidents, each a datum for socio-historical or biographical research. 
Thus it came about that in 1964 , encouraged by being assigned a light teaching load (it struck me as remarkably light, though I found it regarded as a "normal" full-time load in the new Era of the Affluent Academia,) I took pen in hand and broke ground on a monograph which I proposed to call History of the Sociology Department: The University of Kansas, 1889-1965. About the same time the newly launched Kansas Journal of Sociology added its voice to the others urging me to come up with something on the history of our "Sosh Department'. I had succeeded in documenting a slim budget of facts bearing on beginnings of sociology at this university. This preliminary work convinced me (1) that of all phenomena in the bureaucracy of higher education, the academic department is one of the least studied; (2) that the job if done in a way acceptable to a professional historiographer would be a much larger task than anticipated by those who had approached me; (3) that a thorough departmental "social history" aimed at academic professionals in this or kindred disciplines would likely range from dull to soporific on the interest scale, and (4) ideally there should be a serious, critically analytical study of the entire system of higher education centering on the department as a basic unit in both the formal and informal organizations of the modern university. Only a team of researchers that included perspectives drawn from several social sciences could do a bang-up job on this. ${ }^{1}$

What I am doing here, then, is neither a historical nor a sociological study, but a few recollections that I have found, on occasion, many of our present day students like to hear about.

\section{Part I}

What was K.U. like half a century ago? Probably few persons of the several thousands of former students who still survive from that era would wholly agree with any description I might offer. But many may retain images quite similar to those I propose to picture here.

My first acquaintance with K.U. was made in September, 1919. A brother a year and a half my junior agreed, somewhat reluctantly, to join me in giving college a try. Neither of us had settled on a vocation, and in those days a high school education was plenty for most people. We gave little thought to getting a degree - a year or so, if we could manage it, would be enough.

The train that bore us to Lawrence was literally packed with students. They raised such a racket the clicking of wheels on the rails could scarcely be heard. On the run from Solomon to Manhattan several hundred Kansas "Aggies" were thrown into vociferous contact with those of us headed for K.U. Impromptu cheerleaders stood on seats in the "smoker" to bawl out pep yells or chant scurrilous ditties at their rival.
Most of us debarking at the Union Pacific depot in North Lawrence took street cars to get "up town". Only a few enjoyed conveyance by private car. There were of course some who had Lawrence relatives or family friends to pick them up along with their luggage. A few others were hailed by exuberant fraternity brothers or sisters in automobiles. In such cases, it was ten to one that the car had been loaned to an "active" by his well-heeled parents until rush week was past. Only a minuscule minority of students had cars of their own.

There were no dormitories. Students dwelt in rooming houses, unless they belonged to frats. Neither was there a cafeteria. Most students ate at boarding clubs. My brother and I paid $\$ 20.00$ (or ten bucks apiece) for a room in a house that still stands at Seventh and Mississippi Streets. At Eighth and Mississippi we could take a K.U. street car to the Hill for a five cent fare, but mostly we walked. The nearest boarding clubs were on Tennessee Street, south of Thirteenth; meals cost about $\$ 5.00$ a week. We tried several, but I soon got a job playing my saxophone in a cafe across from the Bowersock Theater, thus earning my board. ${ }^{2}$

The fall term of 1919 was marked by the return of World War I veterans, by the great national strikes of the steel workers and the coal miners, and by an almost hysterical wave of distrust of "hyphenated Americans, alien agitators, and subversive organizations" advocating, so it was claimed, syndicalism, communism and anarchism. Many people were apprehensive about demobilization of our armed forces that exceeded two million young men. Practically no government provisions had been made to help them get jobs, or to continue their education, or otherwise readjust to civilian life. There was unrest in the land accentuated by all these factors. Although there was no GI bill as followed World War II, thousands of veterans flocked to the colleges, augmenting the unrest already abroad on the campuses.

How would these roisterous Yanks suddenly cut free from the reins of military discipline behave? In the new world based on President Wilson's 14 points and now "made safe for democracy" (so the "four-minute" propagandists of George Creel had asseverated) would they remain loyal to our basic institutions? What of the built-in privileges, disadvantaged economic classes, and other socioeconomic inequalities that were summed up in the expression "One Hundred Per Cent Americanism"? What if these hell-for-leather "doughboys" and "gobs" should perversely line up with the agitators who were stridently demanding "industrial democracy" as the sine qua non of any valid democracy in our modern world?

The answers to these questions were not long in coming, and the campus vets perhaps more than any group gave voice to them. The American Legion, newly formed veteran's organization, held its first state convention in Wichita and the delegates, representing 10,000 Kansans, adopted the slogan "100 Per Cent Americanism." The first 
meeting of the Lawrence Eli Dorsey Post, after K.U. opened, was held in the G.A.R. room of the Douglas County courthouse with over a hundred members present. More than half of these were K.U. students. At this and subsequent meetings, there was no mistaking the mood of the group, which was conservative if not reactionary in political ideology, and xenophobic in the extreme.

My brother and I were veterans and charter members of the Post set up that summer (1919) in our home town. With our rural background we were not too far removed from many of the reactionary views current at the time.

The daily papers meanwhile shrieked out against the iniquities of the IWW "Wobblies", whose alleged sabotage, such as putting railroad spikes into wheat bundles to wreck threshing machines, 3 and the like, led to passage of the severe Kansas anti-syndicalism law. Even more savage was the tirade of the nation's press against the steel strike. The workers walked out in October, 1919 , headed by the much maligned William Z. Foster, a leader of the American Communist party and later, as I recall, its candidate for president. Both the Communist and Socialist Labor parties were legal and on election ballots.

Equally outrageous, as presented by the dominant news media of the day, was the nation-wide strike of the United Mine Workers led by the bushy-eyed, malevolent John L. Lewis, who defied the arbitrators and the plea by the bed-fast President Wilson, and called out his 350,000 bituminous coal miners on November 1 . Anyone who read the papers or went places where there were mills or mines, was quickly informed of the uprising of "Wops," "Polacks," "Bohunks," "Dagoes," "Hunkies" and other dangerous alien breeds who, stirred by imported troublemakers, were threatening our system of free enterprise by taking over coal and steel and allied industries. 4

Coupled with all this were the tensions between blacks and whites. Few anticipated the social, economic and demographic consequences of the first World War with its labor shortages in defense and other key industries which drew hundreds of thousands of blacks and poor whites from the farms to the cities. Suddenly pressed together in wholly unfamiliar environments, it is not surprising that the friction sent sparks flying that set off explosions in Chicago, Omaha and other cities. Who would have supposed a minor brawl between so-called "uppity niggers" and "redneck whites" on a lake shore beach in Chicago should touch off a race riot of such alarming proportions? Or that a mob of 3000 whites in Omaha would not only lynch and burn a Negro accused of raping a white woman, but would proceed to assault the mayor of the city, who dared to intercede. The press had a heyday describing how the mob cinched the hangman's noose around his honor's neck, mauling him badly in the process, then had him swinging aloft before embattled police managed to get to him and save his neck. Martial law prevailed in
Omaha. The National Guard was supplemented by federal forces supplied by Gen. Leonard Wood before order was restored. If memory serves me, the packing plants in Omaha, as at Chicago, had drawn many new workers, including rural blacks and whites, who presumably were the focus of racial friction. That may have been why St. Joseph, Topeka and particularly Kansas City, all with expanding meat industries (among many others that attracted ethnic and rural workers), became so deeply disturbed by these race riots in middle western cities. 5

But beneath the uproar of domestic conflicts, of which the clash of labor and capital over the right to bargain collectively in major industries was loudest, could be heard the deep rumblings of the vaster international upheaval marking the end, not of a war, but of an era. None of us who eagerly broke from the irksome yoke of the military to seek blithely the rollicking freedom of the colleges, had a ghost of a notion of the meanings of these seismic disturbances. Hence it would be easy to exaggerate the extent to which my generation of college youth gave attention to these outbreaks or seriously studied them as symptoms of social problems.

School held off ten days for "rush week", a gay but hectic orgy among the frats marked on this occasion by unprecedented ferocity of competition for the clutch of prize prospects. Those qualified by lots of "spondulics", familial status, a colorful war record preferably with some tangible credentials, and easy access to, or ownership of, a motor vehicle, were pretty sure to get bids. Of course a combination of these attributes, plus a suave and knowing manner, and even high school grades up to, but not necessarily above, a "gentleman's C", contributed to the desirability of the rushee and the pressures of a rush. I cannot recall once hearing mentioned, during my undergraduate days, high school scholastic honors as a factor to be given weight in choice of pledge material. But then I may not have been in a good position to judge. My brother and I had a cousin in school who graciously met, guided and set up things for us in his fraternity. Neither of us were genuinely interested, especially since we did not know where the money was coming from to meet the added expense. The night before bids were tendered and the pledges "yelled in", we ungraciously declined to go to the frat house for dinner - an inexcusable gaucherie and a raw deal to a pal who had been more like a brother than a cousin throughout our boyhood, as I now look back on it. But at the time being told that wearing garrison shoes or khaki shirts was taboo in the frat seemed to smack too much of the military from which we so recently had escaped. Thus we chose to be "barbs" before learning the verdict of the actives.

The cleavage of Greek and "barbarian" was a far greater gap then, I believe, than now, and probably has steadily diminished in the Affluent Society. But in those days more than any single factor, it shaped the 
campus class system. This was owing to the direct effect it exerted on other status differentials through a narrowly selective process. The question was seldom raised whether choices based on race, religion occupation, family name, property (still perhaps weightier than income), rural-urban backgrounds, and other factors affecting class position, were out of harmony with American ideals. On the contrary, the assumption was generally made, I think, that the fraternities attracted and cultivated the best in leadership and developed loyalty, school spirit, and the shibboleth of 100 per cent Americanism.

These slogans were almost obsessively dwelt upon in the University Daily Kansan and became part of a weird "loyalty campaign". Professor Melvin of the K.U. History Department put forth the slogan "Put K.U. First" that won approving editorials. An organization of AEF (American Expeditionary Forces) veterans was formed to revive and stimulate K.U. school spirit, as one member put it "in the spirit of the Argonne". The enthusiasm spread to other organizations and resulted in an effort to persuade every organized group on campus to take a formal pledge of loyalty, which many did before some groups began to ask what were the goals of the loyalty campaign.

One answer was that K.U. traditions must be enforced. It was traditional that all male freshmen wear a special cap at practically all times they were on campus. A few weeks after classes began, a foolhardy "frosh" dared defy the edict, vowing in a letter to the Daily Kansan's Campus Opinion column that he would never submit to this childish custom. The next day paddle squads roamed the campus, invading class rooms, until they flushed him forth. A hot chase ensued with the fugitive racing to the top floor, then to the roof, of Old Fraser where he climbed to the top of one of the north ventilators. Armed with a two-foot length of heavy gas pipe he held off a menacing paddle platoon of upper classmen. A swarming crowd of onlookers gathered below, and witnessed a show that had all the antics and suspense of a Harold Lloyd comedy. The Superintendent of Buildings and Grounds recruited a squad of janitors who tried to force the paddle platoon down from the badly trampled red tin roof of the old building, their aim being not so much to save the freshman as to save the roof. During the scuffle that took place, the fugitive swung down off the roof and, clinging to ledges like a human fly, descended the walls to windows of classrooms below. Finally he found sanctuary in the Chancellor's Office on the first floor. The tradition upholders surrounded the office and called for their victim. After a half hour of negotiations, it was agreed that the culprit should be thrown, or jump, into Potter's Lake forthwith, and in the future wear his cap as prescribed. Though it was getting late in the day, several hundred students remained to see the defiant frosh leap, fully clothed, into Potters. A few weeks later he withdrew from school.

\section{Part II}

College life, I quickly discovered, was much to my liking. After the igors of military service, the light yoke of university discipline and rigors of military service, the lo bumptious demands of paddle squads bent on enforcing an asinine loyalty creed, scarcely galled me. As was true of many veterans, I mostly disregarded the mandate that freshmen must wear "beanies," though I discreetly carried mine in a pocket when on campus so I could don it whenever a gang of tradition-enforcers came in view.

Actually, the service veterans in the freshman class, being older (I Actually, 21) and perhaps less easily identified as frosh, were not was past 21) and perhaps less easily identified as frosh, were not like "good sports". After all, were not we who had vanquished the Hun like "good sports" Arld safe for democracy, the arch expemplars of institutional loyalty? How could we violate the traditions and codes institutional loyalty? How could we violate the traditions and codes that gave stability to the established social order whether in or out of looking for trouble?

What pleased me most about the new life was the association with my the students, not necessarily "brains," who had my teachers and with those students, not necessarily "brains, "who had colloquies were touched off by the lectures or discussions in our classes. I delighted in the courses I took,-Rhetoric, English Literature, French, and Economics, but didn't go around saying so, as it would have sounded naive. There was one exception, namely a non-credit course in Hygiene. This course consisted of a one-hour lecture or film each week that started off detailing the horrors of venereal diseases (then always referred to as "social diseases" in the press.) Here students might learn referred to as "social diseases" in the press.) Here students mit of the less headstrong and concupiscent. But the course duplicated, even to the use of the same films, the basic training hygiene course I had received in the Army. Accordingly, after a few weeks of these boring sessions, I the Army. Accordingly, after a few we I didn't bother with the finals. But at the end of the term I was shocked to find a red F on my report But at the K.U. Catalogue I discovered I could not card. More graduate without a passing mark in this course. Neeturs to repeated the course the next semester. This time the lectures were given by Dr. Naismith who, besides being the inventor of basketball proved to be a wise and genial philosopher. This incident helped me in later years when I served as a faculty adviser, to understand better the plights of when I served as a faculty adviser, to understand by treating rules and the many hapless freshmen who were tripped up by treating rules and requirements in a cavalier fashion, seldom bothering to read them. Such find someone to understand them. 
Just after mid-term exams were out of the way and I was congratulating myself on getting good marks in all credit courses, an unexpected turn of affairs rudely disrupted the even tenor of academic life at K.U. The national coal strike did not spare Kansas. Alexander Howatt, head of the miners union in the tri-state coal area had followed the orders of John L. Lewis calling out the UMW on November 1, 1919. The university and all state educational, penal and eleemosynary institutions at that period depended on coal for heating their buildings. A small fraction of their supply came from convict-mined coal from Lansing but the bulk came from the mines of southeast Kansas. Consumption by K.U. ran to five or six car loads per week in mid-winter, and because of storage difficulties, only a small supply was kept on hand. By mid-November every economy measure was being observed to conserve fuel. Class rooms were chilly and the Library was the only building kept heated at night. I wrote home for my long-johns. As the Thanksgiving recess approached and the coal supply dwindled, Governor Henry J. Allen asked the State Supreme Court to grant a receivership for the coal companies, clearing the way for the state to take over the mines. He proposed to recruit volunteer labor to turn out enough coal to meet the more exigent needs.

Returning after a trip with the Band to Columbia, Mo, for the annual football game (which, alas, $\mathrm{KU}$ lost) I first heard that the five state schools might be asked to raise a quota of volunteers from their student bodies. On November 28 the press carried Gov. Allen's proclamation announcing that the State would "protect its suffering citizens" and keep the colleges from closing, by taking over the mines. Tensions mounted rapidly.

This was the setting that led to my brief adventure as a coal miner - of sorts. Looking back on it now, it strikes me as an experience of much greater educational significance than I recognized at the time. What it did was to prepare me for what might be called an ideological sea change. The introductory economics course I was taking with Professor Duffus (employing a text by Richard T. Ely,) the English courses of Professor Laird who had a deft way of challenging one's uncritical assumptions, and of course the exposure to talks, readings and casual contacts that in a university combine to exert a broadening effect on a provincial mind - no doubt all these influences were beginning to work as a seepage through the crust of my small-town biases. All that was needed, it seems now, was a direct confrontation with some of the concrete conditions that, as generalized in textbooks, were left pallid and unreal.

The interval between Thanksgiving and Christmas was chaotic. As school resumed the campus buzzed with a Great Debate - "to go or not to go." Rumors abounded that the miners were arming and would wage civil war to prevent volunteers from entering the mines. The governor called out the Fourth Infantry, Kansas National Guard (about 1200 men, many of whom were raw recruits) and General Leonard Wood promised 600 regular troops to lend aid in maintaining order. There was the question about loss of credit if the strike held on and student volunteers missed the rest of the semester. The Administration, evidently nonplussed, did not immediately announce a policy on this point. The talk among the veterans largely favored volunteering, but parental opposition and other conservative restraints deterred the majority. Meanwhile, a terrific blizzard was reported, sweeping into the majority. Meanwhile, a terrific blizzard was reported, sweeping the Rockies with sub-zero temperatures. This added gravity to the crisis, but also cooled off the ardor of some who had welcomed the proposed expedition as a lark. Working open strip mines in mid-winter was known to be rough at best.

My brother and I had made up our minds to offer our services. However, we missed the first contingent of volunteers that shipped out on November 30 . We delayed because our cousin, who wanted to join us, was struggling by long distance phone to get parental approval. His efforts failing, brother and I signed up next day in Robinson Gym where Dr. Naismith had been put in charge of arrangements. That night we joined some 90 other K.U. student volunteers at the Santa Fe depot where all boarded a special train for Pittsburg.

There was little sleep on that trip that night. The cold wave was moving in as forecast and the chair cars were poorly heated. A few fellows had obtained a bottle or two of bootleg gin which after a couple of slugs warmed them into song and revelry. Soon the rest of us joined in, (most without gin,) warmed by the ebullient spirits of youth, quickened in the cameraderie of militant enthusiasm and the quest for new adventures. In those days I knew all the tunes, could ad lib off-color lyrics and wielded a throaty baritone.

On arrival at Pittsburg we bivouacked at a former S.A.T.C. barracks on the State Normal School campus until next day, when we were transported by truck to a road lined with rude shacks of miners, between the iced-over furrows of abandoned strip mines. Here we disembarked and were led on afoot by a platoon of National Guardsmen. We passed several small knots of men in the rough garb of laborers, many with moustaches or beards gathering frost from their steamy breath. Some women with shawls drawn about their shoulders and shy children huddling against their billowing skirts watched from the door steps as we marched by. Clearly word of our coming had preceded us. As we had passed through the outskirts of Pittsburg a few angry jibes of "scabs! " had been flung at us, but here in the mining village not a voice was raised. The faces of those close enough to be read appeared stolid and grim, but expressed neither anger nor fear.

For this chronicle, some details of the two weeks that followed seem relevant. At our destination we were quartered in army pyramidal 
squad tents heated after a fashion with Sibley stoves. You could scorch your face while freezing your back. Even in summer, this housing would no doubt be considered substandard. But most of us had recently put up with far worse, in the field or shipboard. Indeed, each of the six men, all service veterans, with whom I shared a tent, thought that the quarters were quite adequate and that our set-up had a fair portion of amenities. The chow, supplied by the K.N.G. company, was fair to good; there was a plentitude of coal at hand and no point to economizing on it; the supply officer was liberal with blankets; mail was delivered daily; we stood no K.P. or guard duty; and there were no irritating indignities such as "short arm" inspection.

Of course there was some griping on minor inconveniences - just enough, in fact, to indicate our morale was in a healthy state, if one may believe the military pundits who are generally accepted as knowledgeable about such matters. Some of the "gobs" complained of the army cots with lumpy straw-tick mattresses, a few going so far as to try to improvise hammocks from tarpaulins and blankets; nobody was happy with the dirt floor which gradually turned to gumbo as we tramped in and out in snowy boots, and there was some dissatisfaction with the furniture furnished us which consisted entirely of wooden crates, hard and full of splinters.

But as the first days passed, a wholly unexpected source of frustration and discontent became manifest. We had been told that in our contingent would be men who would know all about mining operations as then conducted in strip mines. When the Governor had first acted, a special plea had been issued for anyone who had ever operated a steam shovel, handled high explosives or worked on a railroad. Some desultory questioning, aimed to get at such skills had been attempted by Dr. Naismith's helpers when we signed up, but if my own case can be taken as typical it can readily be seen why it went awry. I had been asked about my military training. I merely replied it was in a Coast Artillery regiment equipped with 12 inch mortars, these being mounted on railroad flat cars in France. Immediately my interviewer had said, "Fine, just what we're looking for. Next man, step up! " I might have explained that all I learned to do on mortars was to work the azimuth instruments used in range finding, and that my experience with railroads in France was confined to riding on the "Forty and Eight" boxcars, hither and yon, in the aimless, incomprehensible mode that was S.O.P. in the military system. If as I assume, the recruiting was thus careless and indiscriminate it is small wonder that we found ourselves shivering amidst the strip mines without the leadership or know-how necessary to get out a few car loads of coal.

Dejection began to descend on us as we gradually realized our plight, and this was accentuated by press clippings mailed us by friends and relatives telling of the successful exploits of the first K.U. contingent of
42 men led by the redoubtable Wint Smith. This group had enlisted a newspaper correspondent, several widely known campus leaders, and most of the K.U. football team. They had, by these accounts, mastered all obstacles and were extracting several carloads of coal daily, and had defeated a rival contingent of Kansas Aggies both in coal output and in a football game played on a snowy field.

But among our ranks were intrepid youths long on that ingenuity to which Yankees and indeed all red-blooded Americans have laid a claim. These informal leaders decided to take action. Among them were a couple of stalwarts who had worked on threshing crews and knew something about steam engines. They headed a team that after a few hours managed to get pressure building up in the steam shovel. Another team coalesced around a sophomore mining engineer and a freshman law student, the latter having had some experience with explosives during summer work in a rock quarry. I was delegated to this team by a viva voce mandate, no doubt derived from my heedlessness in making known too widely my background as a heavy mortar man. The mission proposed for this group was to plant, wire and detonate the dynamite about to be exploded to break up the coal vein. It was a chilling prospect, at least from my skeptical point of view.

Almost immediately upon uncrating a box of the explosive, an acrimonious dispute arose between the engineer and the law student. The former maintained that the dynamite sticks were frozen solid, which put them in a condition so they were dangerous and could not be used until thawed out. The latter held that this would occasion delay and was wholly unnecessary. Although I thought the law was making the more plausible argument, the engineer, by dint of his stronger lungs and prestige based on his courses in mining, appeared to be winning out. Finally, this fellow seized a stick of dynamite, carried it to the shovel, and turned on a valve releasing a jet of hissing steam. At the same time he shouted that immersing each stick in steam would thaw out the stuff as fast as we could use it.

Just then I happened to recollect that this was the day I had been detailed as mail orderly, and it was nearing the hour scheduled for the mail to arrive. True, the mail invariably arrived late, but then who would predict in this wholly snafued situation that it might not some day come in on time or even beforehand? As I have previously taken pains to suggest, the regular receipt of mail is an important means of keeping up morale. So I promptly left to get it.

I never did obtain a clear account of just how they did it, but the differences among the self-elected leaders of the teams were somehow resolved with no fatal casualties and in a few days we had loaded a car of coal and moved it by pry-bars to a railroad siding, Then, unfortunately, our shovel went out of commission and since we could find no experienced mechanics to diagnose the trouble and make 
repairs, again we were stalled. There was talk of sabotage by the strikers, but no evidence to support it. People had talked of sabotage from the start and the press kept hinting at it, just as it had of armed resistance on the part of the strikers, with little occurring to bear out these anticipations.

The enforced idleness gave our group an opportunity to get around and become acquainted with the "natives". There were martial restrictions posted in ordinances about this and if one stayed out after the bugle sounded "call to quarters", he might have his head shot off by a trigger-happy Guardsman. But most of us managed reasonable freedom of movement, some even visiting Pittsburg against orders in the effort to escape boredom.

Looking back through the haze of almost half a century, it strikes me that the big pay-off of my first year in college came out of the lay-offs which permitted me to get some idea of what the life of miners was like. In a brief confrontation, I glimpsed what manner of men were these polyglot aliens and their native-born sons, who thus struggled against big odds to wrest a precarious livelihood by working the niggardly marginal mines in this "Little Balkan" section of Kansas.

I can not clearly recall many of the individuals I talked with or just what was said, but I still recall the impact they made on my emerging social conscience. There was one old grey bewiskered fellow who hung onto me, and with eyes glittering like the Ancient Mariner's, told with great earnestness but without marked bitterness, of fleeing the old Austro-Hungarian empire with sons nearing draft age and a clutch of unwed daughters, all thrilled with the promise of this rich and free America. But though some things were better or at least not as crue over here, yet the old man said the miner's lot was much the same and never easy. The bosses did not have you beaten here unless you were too forward in talking up the union, but in the deep shaft mines they had it fixed with the check-off man to cheat you and in the strips would work you overtime without pay. And what advantage if the daily wage was higher if a man was laid off half the working days in a year? This patriarch had left the mines in southern Illinois because work was so irregular there and together with two of his sons and their families had settled in Kansas. Here work had been more plentiful during the war years, but prices kept getting higher, and since the Armistice, his sons were laid off two-thirds of the time. He could no longer work himself, but his sons were good and would keep him as long as they could get work.

Along this line the old man talked, with his son often having to interpret, for the old man's English was very broken. As I recall, they were Slovaks. There were various Slavs, some Bohemians, and a few Italians in the places I visited and while some were unfriendly or held back by suspicion, others seemed quite ready to talk. "Confrontation" nowadays is a word much overworked, but I know of no other that can express so compactly the effects of these fugitive contacts on my attitudes, especially that most significant part of an attitude that extends far below the threshhold of consciousness and was to bear fruit later. Shortly before Christmas the strike abruptly ended. After spending the vacation at home, we returned to K.U. to bone up for finals. No one was given a free ride, but Chancellor Strong promised the student volunteers a "fair deal" and I think we got it from our instructors. Professor Duffus, my economics teacher, visited for hours with me after classes about my mining adventure and suggested things I should read, not only about coal production but about labor problems in the economy of our nation. In the course of the next year I read John Hays Hammond, What the U.S. Coal Commission Found; Paul U. Kellog and Authur Gleason, British Labor and the War; Upton Sinclair, King Coal, and many books on socialism, democracy and the labor movement. I had after-class contacts with my other teachers which did not increase my popularity with fellow students. Then as now the distrust of any apple-polishing and rate-busting were prominent in student culture patterns.

There were of course a number of fellow students as well as faculty with whom I liked to discuss ideas encountered in my readings. One I came to know better and longer than most was Domenico Gagliardo who happened to have been a bona fide coal miner in the Kansas mines before joining the Navy for the war period and then coming to K.U. Many evenings after playing dance jobs I would drop by the old Jayhawk Cafe at Ohio and Fourteenth where Dom worked on the late shift. Then we would argue the pros and cons of these absorbing social and economic problems while I consumed a bowl of chili or a sandwich. He was already interested in compulsory arbitration of labor disputes, an expedient that had only recently been innovated in Australia. Later he was to become the author of the definitive work on the Kansas Industrial Court law which embodied similar principles and was enacted through the efforts of Governor Allen and his supporters in the aftermath of the coal strike. He will reappear in later sections of this narrative.

When I entered K.U. in the fall of $1919 \mathrm{I}$ had only vague ideas about vocational goals, but I leaned toward journalism. I had been high school correspondent for the home town newspaper, and greatly admired its editor who previously had been my teacher and high school principal. If I had heard of sociology in those years, I can't remember the circumstances. The word carried only a vague denotation in my mind even when, in my sophomore year, I enrolled in my first course in the subject, Elements of Sociology, taught by Delbert C. Mann. At the same time I enrolled in my first course in Journalism, Reporting I. The latter proved disappointing while the former gave focus to the interests 
I was developing and kindled my imagination with its broad (but often vague and conflicting) generalizations. Mann was not a brilliant lecturer but had a deep earnestness in his approach to the subject and a willingness to accept any sincere student as a co-learner. His influence unquestionably was an important factor in leading me to choose sociology as a major, which I did next term. Like Gagliardo, Mann became a close, long-time friend.

In 1919 Frank Wilson Blackmar was chairman of the K.U. Sociology Department which he had founded 28 years before. According to his claim this was the first social science department in the country to bear the label "sociology". He had also been Dean of the Graduate School since its founding in 1897 , and had just been accorded the coveted honor of President of the American Sociological Society. Of course Blackmar was widely known throughout the State not only for these positions but because his classes had been extremely popular for the past thirty years; many of his students were teachers in smaller colleges and high schools; he had developed university extension courses that took him out over the State, and he was perhaps the foremost leader in the charity organization movement in the area. He was one of a few "old hands" who had served at K.U. many years before when my father, an aunt and an uncle had been students, so he had become to me since high school days a great charismatic figure - a dean, a savant, an oracle, a humanitarian. Yet, surprisingly, I had not identified him as a sociologist prior to entering K.U., perhaps because neither the public nor I had any conception of what that meant. Later I was to find that Blackmar had incurred many enmities and, like many charismatic figures, had feet of clay. But when as a junior I took my first course with him, he was a commanding personality.

\section{Part III}

The teachers in the Sociology Department at this time, besides Blackmar and Mann, were Professor Walter R. Smith, Associate Professor Victor E. Helleberg, Assistant Professor Walter Bodenhofer and just previous to my first enrollment in the Department, Associate Professor Manual C. Elmer. I took courses with all of them except Bodenhofer and Elmer. Bodenhofer soon left for the University of Chicago where he became the second graduate student from the Kansas Department to earn a Chicago Ph.D. degree. Later he settled down at Washington University, St. Louis, where he taught until his retirement in the 1950's. Elmer went to the University of Pittsburgh where he became chairman and I believe remained until his retirement. He authored a book on social research that was widely used, and several others.
The man scoring the strongest impact on my budding mentality was Helleberg. Though I will have more to say about him later, I think I should pause here to characterize at some length this strange man and perhaps make it possible for the reader to comprehend how, despite his egregious shortcomings as a teacher, he could stimulate so intensely a good many of us comprising that minority of students possessed of curious, critical minds.

In the first place, Helleberg was not strictly a sociologist but a social philosopher. He had no advanced degree in sociology. His A.B. was from Yale where he had taken William Graham Sumner's famous course in social evolution only to condemn it as "outrageous laissez faire buncombe" and wholly inconsistent with Sumner's major book, Folkways. His only degree other than the A.B. was the LL.B., from Cincinnati University, but he never practiced law and was fond of using the law schools as a choice example of education aborting a sound concept based on the facts of social institutions. In other words, what lawyers must contend with in practice, is discarded altogether in favor of a miasma of principles out of touch with social realities. Having written this, I realize this would never have been Helleberg's way of putting it. He seldom spoke or wrote in sentences of over a dozen words; no dangling clauses for him. Still I think this expresses his idea of the matter.

Helleberg often told me that he was in the photoengraving business in his home town of Cincinnati, and well in his forties, when he came upon the latest work of Lester Frank Ward. I presume he was stirred by reading favorable reviews of Ward's Pure Sociology which was published about that time. Helleberg averred that he was so carried away by this encounter that he threw overboard his Cincinnati business and proceeded to the University of Chicago where he was warmly received by the Chairman, Albion W. Small. I can imagine what a strange impression he must have made on Small and Henderson with whom he first studied, but they were evidently impressed. However, Helleberg never settled down to write a dissertation that would have insured him a degree and a decent livelihood. Instead he found his way to the Philosophy Department, headed by George Herbert Mead, who had himself little interest in degrees (I believe he was the one and only professor in the University of Chicago at the time I attended who listed only an A.B. after his name! ). The fervor of Helleberg's devotion to the pragmatic philosophy of Mead, Dewey, James, Tufts and their less well known predecessor, Charles $S$. Peirce, ran like a theme song through all of his K.U. classes from the first day he began to teach.

How Blackmar ever came to hire this intractable philosopher lies beyond my powers of divination, for no human personality could have been devised even by the best computer that would prove so well calculated to fill Blackmar's later years with gall and wormwood. 
Nevertheless, hire him he did in 1910. (In those days Blackmar was pretty much a law unto himself where sociology personnel was concerned and hired whom he pleased. The same was not true of his control of the personnel or policies of the other social sciences combined at earlier times under his headship, at least after history and later economics had broken away and became independent.)

Coming into Helleberg's Psychological Sociology class in the summer of 1921 , I was at first aghast at the reckless impunity of the man in contemptuously belittling Blackmar's text as mostly balderdash, and completely out of date. Speaking thus of his chairman, I soon found, was for Helleberg not at all unusual, representing in fact one of his mildest tantrums. He would lash out not only at sociologists but at other colleagues on the faculty. A reputable biologist, he claimed, hadn't yet caught up with Agassiz, let alone Darwin; the two members of the philosophy department were hopeless Platonists mired down in absolutes; the head of the psychology department was a blind follower of a venal advertising man, John $B$. Watson, who had thrown the baby out with the bath water by dismissing all data of consciousness, and so on. Helleberg seldom succeeded in coherently completing these indictments of errant colleagues or misguided theories. His choleric energy mounting, he would sputter disjointed ejaculations, sometimes with such force that flecks of spittle would spray those of us in the first row of seats. After a week or two I took to sitting well back.

There were other deficiencies besides his scurrilous way of criticizing colleagues, adminstrators and many others which he would do in or out of class and in even more public places. I will mention only a few, omitting some details lest it seem that I bear a grudge against my old mentor, and seek maliciously to degrade him. On the contrary, I soon became very fond of him and still remember him with affection despite some ambivalences, which, as this tale unfolds, I think most readers will readily understand.

Helleberg was not a good listener and would seldom wait out a student's recitation. Often his class sessions became dull as he read long sections of articles in class, even reading from untranslated works of such authors as Gumplowicz, Wundt or Ratzenhofer in the original German, then translating them for the benefit of those still awake. (Of course practically no Kansas students knew German because in the heat of the war-time chauvinism it had been expunged from high schoo curriculums. But even had they known it, few would have been enthused by Helleberg's rendition of Gumplowicz, Wundt or Ratzenhofer.)

On occasion Helleberg would mortify student after student by shooting a tough question to the party in the far left corner of the room, then moving along row by row until the question was answered or more likely until he had polled the entire class with no success. One such question I recall from his course, The Family. To illustrate kinship classification he asked, "What would you call any woman over twenty and under forty if you were a youth in the (such-and-such Polynesian) Islands?" Then as indicated, he went all around the class of forty, getting only embarrassed negatives, but passing me by. This was in 1924 and I had just become an assistant instructor teaching my first college class, as the students well knew. After getting his last dismal headshake, he looked in my direction and said with what to me looked like a smirk, "Well, Professor Clark, we'll have to let you tell us." My impulse was to reply, "How the hell would I know?" But I thought better of it. I meekly said, "I'm sorry sir, but I don't recall finding this in any of the readings assigned us." As a matter of fact, it hadn't been assigned except in a very general way. Helleberg had one blanket supplementary reading assignment for every class, namely, the social science holdings of the university library. My experience on this and a number of similar occasions left me decidedly crestfallen but somehow the other students seemed to get a bang out of seeing me deflated. There is no way of fathoming the undergraduate mind.

Now for some of the good qualities of Professor Helleberg which for some of us outweighed all the bad, and drew us like a magnet to him and the little circle that was always formed around him at his home south of The Hill on Mississippi Street. The man never said a critical or abusive word about any person high or low that he wouldn't as willingly have said to his face. Never until then had I known anyone so blunt, ignoring all tact, flattery and even civility in favor of ruthless candor. He was no respecter of persons and never could be cowed by rank or position. After becoming an assistant instructor and sharing the sociology office with its four other members, I soon heard him tell off Dr. Blackmar point-blank in terms far more blistering than I had heard him use when the latter wasn't present. Other staff members fared similarly if expressing some view eschewed by the old curmudgeon.

One day I heard him hop on Dean Brandt. It seemed the college administrative committee had killed a move undertaken by the Department at Helleberg's behest, to increase the credit hours of one of the latter's courses from two to three hours. I had boarded, at 17 th and Tennessee, a street car going from the university to town, and immediately heard Helleberg's voice loudly chastizing the Dean. He was "an exhumer of dead languages", (Brandt was a classical scholar,) was "totally incompetent to pass judgment" on anything having to do with a sociology course, and the members of the college administrative committee were for one reason or another equally inept. Each, he proclaimed, was seeking to aggrandize his own field by holding sociology down. 6 The Dean was making gestures that obviously indicated he wished the interview terminated. I decided it might be expedient to get off before I was observed, so left the car at 13 th and 
walked to my destination. Anyway, I needed the exercise.

Another time Helleberg was charged with contumacy after he had defied both Blackmar and Dean Brandt. The issue concerned Helleberg's insistence on refusing to withdraw his course, Development of Social Theory, when too few enrolled. The legislature had been panning the State Colleges and the University on the issue of small classes. Summoned to the Chancellor's office, Helleberg ignored Dr. Lindley's greeting and refused the chair proffered him. He stood haughtily while the Chancellor explained the problem, expressed disappointment at Helleberg's "unco-operative behavior," and wound up by mildly stating that surely no dedicated teacher would be satisfied to teach only a dozen students when experience had shown he could draw two or three times as many by offering some other course. Finally, supposing he had sufficiently made his points, Dr. Lindley paused, smiling indulgently, and awaited the culprit's response. Helleberg growled, "Is that all?" The Chancellor nodded, still smiling. The professor stood rigidly, glaring ominously until the Chancellor's smile began to fade, then snapped, "Jesus had only twelve," did an abrupt about face and strode out before his superior could collect himself to get in another word.

I first heard this story from Mr. Helleberg and long afterward when I had become acting Chairman of the Department, from Dr. Lindley. Thus I can vouchsafe the accuracy of the essential details. The Chancellor still regretted not having got in the obvious retort. It was, as by that time I had come fully to realize, that Helleberg, for all his insistence that he was working to build a positive science, was the kind of teacher who jealously sought disciples. But to return to his more commendable qualities as I was discovering them in my years as an undergraduate major.

The man had read everything and would talk about books and articles in a way that would make you want to read them. This was true even if, as happened on occasion, he denounced the author's work as perpetrating a monumental error. He made the offense seem so bad you wanted to turn the pages yourself until you beheld it in all its gruesome details. By the same token, he could cast an aura of seductive brightness around some dull work like John Dewey's Experience and Nature or M. C. Otto's Things and Ideals that inveigled you to stay with them to the last page.

Helleberg had a viewpoint. He put ideas, despite his clumsy diction, into a cogent order that from a social-psychological standpoint opened new and enlarged vistas. Building on the "functional psychology" of that era and employing the Cooley, Mead and Dewey conceptions of human conduct and the genesis of the social self, Helleberg advanced far ahead of most of those who were teaching the courses and writing the textbooks covering that field at the time. It was a great pity that he could not more effectively communicate his thinking to others; particularly is it a misfortune that he could not write a book that systematically presented in clear-cut, objective exposition his thinking as it had developed by 1922 , or any time in the 1920's. 7

In the fall of 1921, Helleberg asked me to join the informal, non-credit seminar that for years met regularly at his home. There I saw immediately why he did not write, why he never went to faculty meetings or the American Sociological Society's annual meeting, why he belonged to so few organizations, why he never practiced what he preached about responsible citizenship and leadership in community affairs. His wife was a mental case. It was necessary for him to stay close to her as much as was possible. As far as I know he never was away from her a single night during the more than twenty years that I knew them. Soon after Mr. Helleberg died in 1944 (I was absent in military service at the time,) his wife had to be committed to an institution for the mentally ill. She outlived him by more than a decade. At the reading sessions in his home she would not infrequently interrupt but he would say, "There, there, Dearie, it is all right," or "I'll take care of it just as soon as we are through with our work here." I never saw him lose his patience with her; he treated her kindly, often tenderly, even when she became wildly abusive toward him as was not uncommon in the 1930's.

Finally, Professor Helleberg had a dream, and in his better years (the period before the late 1920's) he could infect students with it so they shared it and tried to work for the ends envisaged in it. This dream caught the spirit of the unlimited potential of America for human fulfillment. It was much like the dream depicted by Walt Whitman, Carl Shurz, Carleton Parker, Jane Addams. Herbert Croly and many another great American before the disenchantment came as it was found that the world was not made safe for democracy after all, and that our social, economic and political ills could not be banished by any simple remedies. But the approach advocated by Mr. Helleberg to make the dream come true bore a closer resemblance to that implicit in Cooley, Mead and Dewey and like them, he retained as long as he lived an optimistic faith in the role of science and informed public opinion to release the potentialities of America.

If I seem to have dwelt overlong on this comparatively unknown social psychologist, it is not merely because of his intellectual influence on me and some of my fellow students and colleagues. In a small department with many of the characteristics of a primary group, a person such as Helleberg inevitably gets you involved one way or another. I cannot disguise the fact that he did indeed get to me in a way that intensified the growing problem he made for me and for the Department during the early years of my chairmanship. But that will come later. 


\section{Part IV}

Next to Helleberg the man who played the most significant part in my career, and a role even more important in the affairs of the Department until the end of World War II, was Professor Seba Eldridge. Seba, for benefit of the curious, is a name that appears in some obscure passage of the Bible. Professor Eldridge told me where but not being a biblical scholar I never could remember the place. Most probably the name appeared in one of those dreary chapters of the Old Testamen wherein reports are filed of who knew whom of the opposite sex and who conceived and who then begat such and such progeny, stretching through a long series of generations. In those days such data seemed to have constituted a major section of the vital statistics. Eldridge was not a biblical specialist any more than I but he had a remarkably thorough acquaintance of that book for a man who regarded Robert Ingersol and Clarence Darrow as far better authorities on what to believe than any pope or bishop. When we became close associates he would tell with a twinkle in his eye about the bible-raised folk culture of the Carolinas where he was born and raised. It would have surprised most of the administrative officers of the University to discover that Eldridge had a notable sense of humor, for he early established himself as a dark pessimist about the state of the world and its unpromising prospects in a poorly governed universe. Like Helleberg, Eldridge was allergic to deans and Chancellors. The time came when, for the sake of the Department, I felt I had to strive to prevent both these able but highly individualistic professors from colliding with the administration. However, this is getting ahead of the story.

When Eldridge joined the Department in 1921 he bore few marks of his rural North Carolina background, though he long continued to draw on it for classroom examples. His manner was urbane and his diction, both oral and written, excellent. Like Frederic LePlay, Vilfredo Pareto, Cooley and several others who became pioneers of sociology, Eldridge started out to be an engineer, taking his first degree in civil engineering at North Carolina State. One year spent in that line of work left him so dissatisfied that he scraped together sufficient means to go to New York City, where he obtained a job in a social welfare agency. Even before this he had set his mind on getting more education not in engineering but in philosophy or in the social sciences. Accordingly, he enrolled in sociology with Franklin H. Giddings at Columbia University. Working part time he completed first an A.B. degree at Columbia and later the course requirements for the doctorate. While he took graduate courses in sociology and political science, his concentration was in social philosophy. Before coming to K.U. he had taught at Smith College and Rockford College and prior to that had served three years as secretary of the social betterment department of the Brooklyn
Bureau of Charities. His appointment to the K.U. faculty was at the rank of associate professor, although he had not yet received the doctorate. However, he had already dug his teeth into a philosophical problem of a socio-biological nature, and eventually persuaded John Dewey and the Columbia Philosophy Department to accept it as the subject of his dissertation. In 1927 he received his doctorate. His thesis, done under Dewey, was published later as The Organization of Life.

My first class with Mr. Eldridge was an experience that at the outset was hardly calculated to generate any enthusiasm of either of us for the other. I should explain that circumstances had arisen which led me to consider completing my college course in three years instead of four The university had followed the lead of others in the Middle West and was permitting its various schools to allow what was called "military credit" to veterans. This largess, I presume, was bestowed on the theory that a man must have learned something from military service if only how to keep his nose clean. Be that as it may, I figured that by carrying the maximum allowable course load and going to summer school, I could finish in three years instead of four. At first the idea didn't appeal to me very strongly as I liked college too well to want to cut it short. However, I did attend summer school in 1921, mainly to accumulate professional credit in education that might be used in getting a secondary school teaching certificate.

Suddenly it became necessary because of an accident in my family for which I assumed responsibility, that I get out of school and go to earning with the least possible delay. It was under those circumstances that I enrolled in Professor Eldridge's two-hour course in Rural Sociology in the spring term of 1922 . I was loaded to the limit in the strenuous effort to graduate in June. I tried for the first time, and I hope forgivably, to enroll in several "snap" courses. I cut out several non-essential extra-curricular activities. Dropped was the solo composition Director McCanles had asked me to work up for the K.U. band. I passed up all dance jobs (but I continued to play with a piano man for meals;) and I quit several positions on student committees (Pan-Hellenic Council, Pen and Scroll, and the like.) I was ready to go all out down the home stretch.

Eldridge's two-hour course looked like a soft touch (I don't know the current student slang, but a few years ago the term "pud course" was applied to the classes that required a minimum of effort beyond occasional attendance.) Being new to the staff, none of our "sosh" majors could give me the low-down on Eldridge, but everyone who had taken Rural said it had always been easy. Never was I more cruelly deceived, though only gradually did my plight become apparent.

Mr. Eldridge was a man of small physical proportions, mild manner, pleasant voice, and an easy presence that was nothing if not reassuring. Like Helleberg he remained seated behind his desk throughout the 
entire class hour, a posture that entices the students' minds to wander. The textbook was simple and having grown up on the farm, there was not much to it that I found new or exciting. Sitting well to the back of the room, I soon began to work during the class hour on assignments for other, more rigorous courses.

Well, this new teacher unexpectedly lowered the boom on me. When he called the roll one day, he asked me to see him after class. Then, and not till then, was it made clear to me, that I owed him half a dozen papers that contained answers to the boring lists of questions he invariably read off to us at the opening of class each day. Of course I had noticed other students writing all this stuff down - some notebook students persist in writing down everything regardless of relevancy, like the jury in Alice In Wonderland. I never was a notebook student, so had to explain lamely I didn't even have the questions, let alone the answers. I promised I would try quickly to bring in the papers called for.

This proved to be a sizeable chore. for each day came a batch of questions to be turned in next session, on top of those I had to make up. The kind co-ed who let me copy the list of questions likewise let me look at the papers returned to her by the professor. I was dismayed. The margins of each paper were heavily annotated with comments, correction and suggestions. Her best mark was a $\mathrm{C}$ - and she had several papers that she had been obliged to do over again. To my untutored and possibly biased mind it appeared she had done enough work of decent quality to have earned a straight $\mathrm{A}$ or at least a $\mathrm{B}+$. What further left me nonplussed was the surprising fact that her spelling, syntax, and sentence structure had been meticulously corrected, as normally happens only in the courses of over-zealous English teachers. The climax to my disconcertedness came when I presently got back the first batch of my own papers. The best mark was a B-. Each hastily concocted answer I had scribbled off had been minutely combed over with corrections and emendations indicated, along with notations on factual errata and unfelicitous sentence structure. It now became clear to me that instead of getting into a snap course, I had unwittingly stepped in a bear trap.

Things moved along from bad to worse. Eldridge now gave us shotgun quizzes that compounded the ordeal of those twice-a-week papers answering the increasingly loathsome sets of questions. Damaging to my pride was the discovery that no matter how arduously and conscientiously I worked, my grades failed appreciably to improve. A student accustomed to A's will usually take it harder if he receives a B than a straight $C$ student will with a D. I read and read the dull literature on rural life and farm problems and presented in my papers a proliferation of facts. That merely provoked a growing dialogue that had started up between us, a written exchange that was the last thing I wanted. When I failed to leave him margin enough for his comments, he would write on the back of the page or add a sheet. Always he was suggesting a propos some point I made in an answer that I read this or that article book or review, and give my reactions next time we exchanged billets-doux. In desperation I tried omitting the numbered order always followed in his listing of questions. Then I slurred over or left out a few of them altogether. Those papers came back with an I (in mild, pleasant-looking teacher of a putative snap course, when I went to Sociology 152 I began to see an ogre of napoleonic size who presided over a torture chamber like Poe's pit-and-pendulum.

Previously I spoke of affairs reaching a climax but that was premature. The real climax came when the class was given the assignment for a term paper. The instructions alone filled three sheets of closely written note paper; the bibliography on the general theme, two more; besides which we were to collect our own bibliography on our specific project. In a state of considerable agitation, I resolved to talk with my major adviser. He had been Professor W. R. Smith, but that gentleman has been transferred to the School of Education. Upon inquiring of the Chairman, Dr. Blackmar, I discovered that my new adviser was to be none other than Dr. Eldridge himself.

Dejectedly I decided to talk with Dr. Smith anyway. I had taken several courses with him and made out fine. He was a good listener and let me pour out all my troubles, never interrupting but chuckling audibly, now and then. It appeared he did not share the dim view I audibly, now and then. It but then it was no skin off his anatomy if I took of my predicament, but then it was no skin off his anatomy if 1 that day that Eldridge had set some kind of record with the number of F's he had dealt upperclassmen the previous semester, one being on the Dean's Honor Roll.

When I finally finished my tale of woe, Smith said, "Wait here," and left the room. I saw him enter the office of Dr. Fred Kelly, Dean of the School of Education, which was just across the hall. He returned shortly and with some more chortles, addressed himself to my problems forthwith. It was obvious he said that my class load was excessive, so he education course. In view of my prior teaching experience, he remarked, it was reasonable to waive it, anyhow. I would still get my University Teachers' Diploma and be certificated, and I would not lack hours needed for graduation. As for my financial problems, he proposed that I should apply for a loan scholarship at once; he would himself speak to Blackmar and the chairman of the scholarship committee to insure my getting it promptly. (I did soon after.) With respect to Eldridge's class, his advice was to take it easy, real easy. He ruminated a few moments, frequently grinning, which caused the small 
tooth-brush-size mustache just below his nose to oscillate. At last he said, "You know, Professor Eldridge is a very fine scholar. He has been a case worker, - he will like cases. You are a native of Kansas, raised on a farm; have been here all your life, while your teacher knows very little about this State or its farms. Suppose you just pick your topic so it covers Kansas farms, and fill it with cases about those farms you know. See if that doesn't work."

I thanked him profusely, feeling a great load already lifting from my chest. As I opened the door to go out, he stopped me. "Clark, about that reading list you showed me: don't waste too much time on it in doing your paper. Rural sociologist's don't have a lot of good material on their field yet; not much more than we educational sociologists have on ours. Browse, hit the high spots, move on unless you come on something you think is really good." I thanked him again, and again started to leave, but he came to the door, continuing to chuckle as he added, "You might use some of that reading material for quotes, and be sure to follow all those instructions for making your citations. It would be a pity to see all those elaborate directions go to waste; good practice for you to use them, too. It might not hurt to do a little padding. Brevity is the soul of wit, but not of sociology." I heard his chortle still following me as I went down the hall, but my step was several tons lighter than when I came that way only an hour before.

From then on the going in Rural Sociology was smooth and down hill all the way. Having regained my cool, I could re-read the instructions for the term paper, and found that they made sense. It came home to me next morning as I climbed The Hill on my way to classes, that the rural slums and miserable share-crop tenancy common in the South, which Eldridge often discussed, had no close counterpart in Kansas. Absentee landlordism and tenancy were of course problems in this region, but of a quite different sort. More than a few tenant farmers I knew were better off than some of the land-owning farmers. Why was this so? With rising ad valorem taxes on farm land and improvements, wasn't the owner of, say, a quarter section of Kansas wheat land becoming worse off than his tenant neighbor? Many such farmers in my home county were having to rent additional land to make farming with a tractor and combine profitable, thus making them tenants as well as owners. My project began to crystallize. What I needed next was a number of cases.

It was at this point that $I$ found willing allies. Dozens of my friends on the campus had been Kansas farm boys; four of us in the same house grew up on farms less than twenty miles apart and knew conditions in our neighborhoods. My queries served to set off prolonged arguments on tenancy versus ownership, and whether farmers weren't fools not to chuck the whole thing and find city jobs.

Thus I soon had a notebook full of cases that covered such data as size of holding, owned and/or rented, type of farming, investment in equipment, livestock, etc.; labor supply, mortgage on owned land, kind of contract between owner and tenant, and so on. Going home for Easter vacation, I pumped the postmaster, rural mail carriers, my old friend the newspaper editor, several relatives who were farm owners, the county clerk and county treasurer. I filled another notebook with more cases and at the courthouse obtained data to confirm or supplement cases on hand. Returning to Lawrence I drew on census data, much of which was statistical and could be conveniently arranged in tabular form. Writing up the body of the study was surprisingly easy. The thing had become a challenge, - I was determined to fill the maw of that insatiable professor with such a profusion of factual material that he would be utterly surfeited. Then I would be through with him forever.

The denouement did not follow this script. I turned in the paper a week before the deadline. Eldridge accepted it with no visible surprise at its extraordinary bulk, but thanked me for submitting it early. At the next session of the class he laid my paper on his desk, discussed the main thesis I had argued, and to illustrate the case method employed, he proceeded to read from the document. On and on he read as the class began to show signs of restlessness. He finally dismissed us at least five minutes past the whistle (which for more than half a century has been the way K.U. has signaled class changes, to the wonder of many foreign visitors. I should add that to hold a class past the whistle is a sin.) As we exited, I got some black looks, and one of the men in the class hissed, "Nice work, Clark, you've made it look hunky-dory for the rest of us." I realized that this was meant to be sarcasm. If in my own extremity I had done ill to any of my classmates, I was then and still am really regretful. The spot I was in was such as to make one think only of saving his own skin.

On the day of the deadline for term papers I should have been at ease but this proved quite difficult for the reason that the room was full of static and much of it was beamed at me. It seems that in the class were many foolish virgins who failed to come in with their papers, which the teacher called for at the beginning of the hour, in lieu of roll call. (The metaphor is not wholly inappropriate inasmuch as four-fifths of the class were girls, and sociologists who research such things claim that the percentage of virgins at that time was much higher than today.) Eldridge did not waste time rebuking the delinquents but announced that each of them was to see him during his office hours before the next session. On reflection, I am inclined to think my magnus opus in Rural Sociology had done him a favor. Previously there had been indications of student resentment aimed at the teacher. As I overheard one say, "What does the little squirt think this is, a five hour course?" But from that session devoted to that opus till the day of the finals, I'm 
certain that I siphoned off the worst of those hostile feelings for myself.

This episode has been recounted in such detail that many readers may already have lost interest. I can only plead that it is significant not only in depicting features of Dr. Eldridge's character, but in casting some light on the confused state of rural sociology in those days Moreover, I look on it as at least a minor landmark in my own confused flounderings in the sociological morass. Over a dozen years passed before I heard the last of that term paper. Eldridge continued to use i every time he taught the Rural course and at times in Elements of Sociology 50 (the section for juniors and seniors,) as well. After I returned to the Department as an instructor he proposed that I publish it, or that we up-date it and publish it jointly. I begged off, being highly distrustful of some of my hastily gathered data. Actually it came as a marked surprise to me to find in studies published in the middle 1930's by Dr. W. E. Grimes, Dr. Randall C. Hill and their colleagues of the Department of Economics and Rural Sociology, Kansas State College, that I had not gone seriously wrong either in my data or generalizations.

Finally, when I first got acquainted with Dr. John Ise (about 1925), he greeted me, "Hail, comrade, I'm always glad to meet a single taxer! "I had not read Henry George at the time and had no notion of what Ise meant by applying this appelation to me. But I learned that his good friend, Eldridge, had shown him my paper. He had been sufficiently impressed to identify me with it over a year later, and recalled that my data tended to show that Kansas farm owners in that period profited little by land ownership except by what Henry George called, the "unearned increment."

When I graduated and left K.U., I had not yet come to know Dr. Eldridge outside the single course. Nor did I feel any gratitude in finding he had given me an $\mathrm{A}$. If any gratitude was involved, I must have felt I owed it to W. R. Smith. Not before 1925 did I establish rapport with Seba Eldridge, and begin to appreciate and admire the sterling qualities of the scholar and the man. Once that relationship of mutual appreciation, respect and friendship was established, it withstood all stresses and strains as long as he lived.

In the episode just closed, I have introduced the reader, assuming his patience held out, to the fifth undergraduate teacher I had in sociology, Dr. Walter R. Smith. If Eldridge was inclined to be a rigid stickler for principles, Smith tended to be agreeably and nonchalantly opportunistic. Helleberg referred to Smith as a "light-weight" and charged him with currying favor with Blackmar, but like most such charges by Helleberg, this was not entirely fair. I would agree, however, that Smith did fall somewhat short of being profound.

Also, I think it likely Blackmar brought Smith to K.U. in the hope he might serve as a foil against Helleberg who was no doubt getting increasingly into Blackmar's thinning locks, if one may so speak of that progressively deteriorating interpersonal relationship. Smith had gotten well acquainted with Blackmar at a time the latter was in the top echelon of the American Sociological Society. At the outset undoubtedly he admired Blackmar's success as a writer of one of the most widely used textbooks of sociology, Smith himself having authored the first textbook ever published in Educational Sociology. Very likely, he was glad to try his fortune with a figure of national reputation. Blackmar met Smith on easy, almost casual terms, assuming a role that was none too common on his part. As I came to know Blackmar later when I joined the staff, he seemed to hide behind his posture of formality, as if he feared the consequences of lowering his guard or of letting people get too close.

Smith did me many favors and I have every reason to feel indebted to him for practical advice, recommendations both oral and written to. employers and others of influence when I needed their aid, and ceaseless encouragement. Yet I cannot truthfully say he taught me a great deal of sociology. Perhaps what I got from him that counted most was more confidence, and some slants of utility in regard to human nature.

As the date of graduation approached, I set two goals, each closely linked with the other but neither directly involving sociology. One concerned the girl to whom I had recently become engaged. Her name was Pearl Holland and she was a sociology major; I had first met her the previous summer in Helleberg's class. She had been entirely self-supporting throughout her entire college career, working first in the Watkins National Bank and later as secretary-accountant at the Ford agency. She helped me recover from the severe shock occasioned by the accident mentioned. I had that spring invested heavily in a diamond ring on the installment plan despite my finances being near rock bottom.

This is not the place, however, to tell the story of the romance which began during our senior year and led to a conjugal partnership that has endured the vicissitudes of forty-six years. I shall bring her into this chronicle only in connection with events that cannot be adequately recounted if she be left out. Needless to say she has played a role in my career the importance of which I can not begin to estimate. At the time of our graduation we had made no definite plans for marriage, for both family and financial problems stood in the way, making it appear we would face a long engagement.

The other goal was that of getting a remunerative job. This now had become exigent. I thought my best chance to earn promptly would be as a social science teacher in a secondary school. With that in mind I had enrolled in the K.U. Teacher's Placement Bureau and with two commercial employment agencies. In 1922 high school teachers just out 
of college with such limited experience as mine were getting $\$ 1200$ to $\$ 1500$. I received several feelers at or near the higher figure. But one day early in May, Professor Johnson who had charge of the School of Education Placement Office called me in to tell me he thought I might qualify as a principal or superintendent in a rural or small town school system. I applied for several positions and in a few weeks was hired as superintendent at Wakefield, Kansas, at a salary of $\$ 1800$ for the nine months school year.

At about this time a group of us, all members of Phi Mu Alpha fraternity, had formed a six piece dance band and applied for a job we saw advertised in Billboard, a magazine devoted to commercial entertainment. We called ourselves the "Kansas University Novelty Dance Band". How K.U. officials would have regarded our appropriation of the unsullied name of the University for a jazz band I can not positively attest, because we never informed them or asked approval of this choice of title. Somehow it just skipped our minds. Considering the bad odor then associated with this kind of music in the opinion of most university administrators, I am inclined to think this title would have met with their strong disapproval, despite our omitting from it the still half obscene word "jazz."

The job applied for was with an enterprise called "The Hollywood Movie Star Ball." This outfit put on dances featuring the presence of real live movie stars, so the ads said. They went from town to town and presumably packed in the local swains and their dates. For who would not rejoice to be on the same floor and perhaps actually get to cut in and dance with a live alleged movie star?

Happily as we viewed it then, we landed the job, undoubtedly owing to the eloquent descriptions of our music furnished by our front man, Harold Shores. (There were of course no tapes in those days to provide a sample of what we sounded like.) Success in obtaining work for the summer added to the elation I felt over being hired as a school superintendent, not to mention winning the hand of the girl I had courted, plus clearing the last obstacle to graduation by making out in Eldridge's course.

Immediately after Commencement exercises I took a train for Oconomowoc, Wisconsin, where the "Kansas University Novelty Dance Band" was to join the "Hollywood Movie Star Ball" touring troupe. I hadn't learned exactly what my wages were to be, but assumed I could count on more than what I had been expecting to earn that summer in the harvest fields. A sense of tranquility descended on me as I dozed in the chair car that night, the feeling that attends successful completion of the Gestalt. One phase was ended, another was begun.

Here I propose to shift the theme of this narrative to take account of other activities and interests not thus far treated but which certainly gave content and meaning to what I was and what I eventually tried to become. Rather to my surprise I have discovered there are more than a few friends, former students and colleagues who are curious to know how I came to be something of a jazzman; what my youth and my background were like before college days; and what I did besides study sociology while in college. This will require back-tracking to my childhood, a scope not originally contemplated when I consented to undertake the foregoing sketch. I turn my hand to the task with some misgivings, realizing that while, as I have indicated, more than a few have expressed curiosity about these aspects of my personal history, a great many more could hardly be less interested. I proceed at a calculated risk of losing what faithful readership this rambling sketch may thus far have attained.

\section{FOOTNOTES}

1 Karl Marx, Elton Mayo, Carl Becker, Kurt Lewin, Thorstein Veblen and Harry Stack Sullivan would be my choice of top-flight battery, if they could be recruited from the land of the shades. Of course, there are some big guns on the firing line of current specialities in our discipline who might be drafted and combined into a task force to do the study, but at a reduction of caliber, I fear. If the metaphor I have used seems unduly militaristic, it can only be because the reader has failed to acquaint himself with the variety, intensity and subtlety of the conflicts that occur in academia, and which probably involve departments more than any other part of the university's forma organization. Since the foregoing was written, my colleague and successor as Departmental Chairman, Dr. Charles K. Warriner, has submitted a research proposal to a government agency dealing with sources of tension and conflict in universities - phenomena that have long engaged his interest.

2 I propose to relegate all footnotes to the end of the article, where they will not get in anybody's way. Footnotes, like chiggers, are in my opinion mostly a nuisance and need an effective repellent. In the Deep South chiggers are called "Red Bugs." - I will footnote by number for these rearguard items. 
3 I had spent a month of the harvest season in the wheat fields. Labor was in short supply; wages were high with many green hands on threshing crews. Breakdowns seemed to be unusually frequent, but it was not easy to prove why. The IWW (International Workers of the World,) did at that time advocate "direct action" rather than the more moderate parliamentary methods. I saw several spikes and iron scraps in sheaves hauled to the separator when working on an uncle's farm in Ottawa County during the threshing. At least two breakdowns were attributed to foreign objects of the sort by the foreman of the crew. Of course a reactionary zealot could easily have planted a railroad spike in a wheat shock, and laid it to the followers of "Big Bill" Haywood.

4 I have not checked the literature to verify all the facts on these riots and strikes of 1919. The Chicago Commission on Race Relations sponsored a study, The Negro in Chicago, A Study of Race Relations and a Race Riot, (Chicago, 1922, ) which I regarded highly when I used it in the Twenties and early Thirties. Another relevant monograph that comes to mind is E. T. Hiller's The Strike (Chicago, 1927.) Both are in the Chicago Sociological series, familiar to sociologists. The two rousing studies of the sadly abortive Interchurch World Movement (1918-27) should appeal to the younger generation of activists and most of those who liked the work of the late $C$. Wright Mills on social conflict, power, class and their interrelations. See The Steel Strike of 1919 and a follow-up study, Public Opinion and the Steel Strikes, the former published c 1922, the latter c 1927. I do not recommend either book as models of sociological objectivity, but still look back on them as preferable to what was published by Warren G. Harding's followers and their venal media.

5 Colston E. Warne, writing on Labor Conditions, United States, under "Iron and Steel Industry," in Encyclopedia of the Social Sciences, Vol. IV, p. 37 (New York, 1937 ed.) states that the effort to organize steel workers in 1919 was initially launched by a national committee supported by the A.F.L. and embracing 24 co-operating unions with jurisdictional rights in the steel industry. He cites the union leadership, headed by William Z. Foster, as claiming that 365,000 went on strike, a figure discrepant from that issued by management or the press, which rallied almost unitedly in the steel-producing states, to support management. Warne summarized the main demands as being the right to bargain collectively, the 8-hour day, one day's rest in seven, wages sufficient to maintain an American standard of living with double pay for overtime, Sundays and holidays, and some correction of grievances that seem almost trivial today. Warne then goes on to say: "The strike was met by a campaign of terrorism conducted by burgesses, magistrates, police and constabulary. Gangs of Negro strike breakers were imported from the south. The failure of the strike in December, 1919, was due not only to the terrorism but also to lack of coordination arising from the weakness of the craft structure, to the action of the steel companies in raising wages and allowing overtime pay in the month just preceding the strike call, to a "Red" scare initiated by the press, to the ability of highly integrated companies to shift production to areas in which the walkout was not fully effective and to the failure of the American Federation of Labor to stand by at critical junctures."

6 Again on re-reading this, I am struck by how much Prof. Helleberg's discourse is lost in translation.

7 Through the help of former students, Prof. Helleberg was able privately to publish a small volume, The Social Self. The late Dr. Sam Strong, Carleton College, reviewed it, not too kindly. (Amer. Jour. of Sociol., c 1940 ? .) 